\title{
Characteristics of bubble volumes in firn-ice transition layers of ice cores from polar ice sheets
}

\author{
TAKAO KAMEDA \\ Kitami Institute of Technology, Koencho 165, Kitami, Hokkaido 090, Japan \\ RENJI NARUSE \\ Institule of Low Temperalure Science, Hokkaido University, Sapporo, Hokkaido 060, Japan
}

\begin{abstract}
I'he air-bubble formation process has been studied experimentally by using five icc corcs from the Greenland and Antaretic ice shects. Bubble volumes in firn-ice samples were measured by a classical method based on Boyle Mariotte's law for an ideal gas. It was found that the bubble volume varies with depth as a function of bulk density in the firn ice transition layer, which is represented by an exponential function of firn density. Air bubbles start to form rapidly at a bulk density of 0.763 $0.797 \mathrm{Mg} \mathrm{m}^{-3}$. This density $\left(\rho_{\mathrm{ib}}\right)$ scems to be correlated with the ice temperature in the ice sheets; $\rho_{\mathrm{ib}}$ increases with a decrease in the ice temperature. $V_{\mathrm{b}}$ shows the maximum value in the density range $0.819-0.832 \mathrm{Mg} \mathrm{m}^{-3}$. The corresponding porosity of the density ranges between 0.110 and 0.097 . This porosity does not seem to correlate with ice temperature or accumulation rate at the coring site. These characteristics of firn densities probably affect the amount of entrapped air in glacier ice (total air content) in polar ice sheets.
\end{abstract}

\section{INTRODUCTION}

Air bubbles in polar glacier ice are formed during the densification process of firn to ice. Air channels in firn become isolated and form air bubbles during the process. This process has been studied by measuring air permeability of firn ice samples (Maeno and others, 1978; Langway and others, 1993) and by measuring total bubble volume in firn-ice samples (Schwander and Stauffer, 1984; Stauffer and others, 1985; Martinerie and others, 1992; Schwander and others, 1993). Schwander and Stauffer (1984) found that this process occurred rapidly from 64 to $76 \mathrm{~m}$ depth in an ice core from Siple Station, Antarctica. The bubble-formation process at Summit in Greenland was examined by Martinerie and others (1992) and by Schwander and others (1993). However, air-bubble formation processes by bubblevolume measurements have not been examined in detail, except for these two ice cores.

We focus on total bubble volumes in firn-ice transition layers using five ice cores from the Grcenland and Antarctic ice sheets and discuss the regional characteristics of the bubble-volume profile. The method of volume measurement is briefly described.

\section{METHODS OF MEASUREMENTS}

For measurements of density and total bubble volumes, we cut cylindrical samples $35-40 \mathrm{~mm}$ in diameter and $40-60 \mathrm{~mm}$ in length. Total bubble volume, defined as the total volume of pores that are sealed by the ice matrix, was measured by a method similar to that developed by Schwander and Stauffer (1984). They employed a classical method based on Boyle-Mariotte's law for an ideal gas (pressure $\times$ volume $=$ constant at a constant temperature). We modified the method as follows: the ice sample was disconnected from the measuring system when air pressures in the system were measured. This modification enabled us to eliminate the effect of vapor pressure of ice during the measurements of pressure drops ( $\Delta P_{1}$ and $\Delta P_{2}$ in the following paragraph).

Figure 1 shows a schematic diagram of our measuring system. For the measurements, volume $V_{1}$ containing a firn ice sample is disconnected from the atmosphere and connected to $V_{2}+V_{3}$ that was evacuated previously ( $\Delta P_{1}$; about 30 Torr). Opening valve 1 , air in the $\dot{V}_{1}$ (atmospheric pressure, $P_{\mathrm{a}}$ ) is expanded to $V_{2}$ and $V_{3}$. After $30 \mathrm{~s}$, valve $\mathrm{l}$ is closed and the pressure drop $\Delta P_{2}$ in $V_{2}$ and $V_{3}$ is measured. Assuming an isothermal process, the impermeable volume of the sample $\left(V_{\mathrm{i}}+V_{\mathrm{t}}\right)$ is measured using the following equation:

$$
\begin{aligned}
P_{\mathrm{a}}\left\{V_{1}-\right. & {\left.\left[V_{\mathrm{i}}+V_{\mathrm{t}}\right]\right\}+\left[P_{\mathrm{a}}-\Delta P_{1}\right]\left[V_{2}+V_{3}\right] } \\
= & {\left[P_{\mathrm{a}}-\Delta P_{2}\right]\left\{V_{1}-\left[V_{\mathrm{i}} t+V_{\mathrm{t}}\right]+V_{2}+V_{3}\right\} }
\end{aligned}
$$

where $P_{\mathrm{a}}$ is atmospheric pressure; $\Delta P_{1}$ is first pressure drop in $V_{2}$ by a hand pump; $\Delta P_{2}$ is second pressure drop in $V_{1}+V_{2}+V_{3}$ by an expansion of air; $V_{1}$ is the inner volume of $V_{1}\left(169.46 \mathrm{~cm}^{3}\right) ; V_{2}$ is the inner volume of $V_{2}$ $\left(82.52 \mathrm{~cm}^{3}\right) ; V_{3}$ is the inner volume of tubes in the mcasuring system $\left(30.58 \mathrm{~cm}^{3}\right) ; V_{\mathrm{i}}$ is volume of the ice 


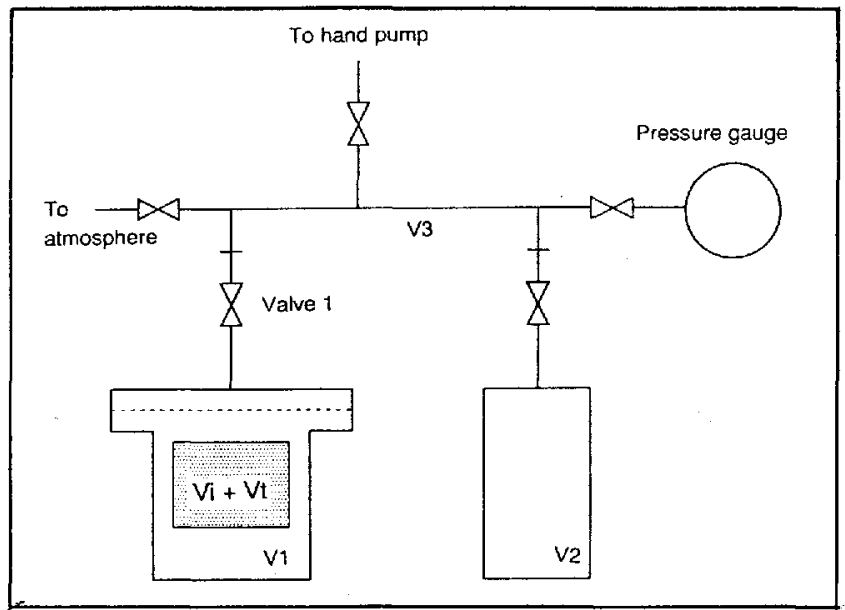

Fig. 1. Schematic diagram of a system for measurement of bubble volumes in fim-ice samples.

matrix and $V_{\mathrm{t}}$ is total bubble volume in a firn-ice sample. $V_{\mathrm{i}}$ is obtained from measurements of weight and temperature of firn-ice samples using a bubble-free icc density (Bader, 1964). The weights of samples were measured with an absolute accuracy of $\pm 0.01 \mathrm{~g}$ and tempcrature was measured with an accuracy of $\pm 0.1^{\circ} \mathrm{C}$. The pressure drops $\left(\Delta P_{1}\right.$ and $\left.\Delta P_{2}\right)$ were measured with an accuracy of \pm 0.04 Torr (type PH-22-D, SOKKEN Co. Ltd). Then $V_{\mathrm{t}}$ is calculated from Equation (1).

Bubble volume $\left(V_{b}\right)$ is defined as the total bubble volume $\left(V_{\mathrm{b}}\right)$ per weight of the sample $\left(V_{\mathrm{b}}=V_{\mathrm{t}} / m ; m\right.$ is the weight of the sample). Air-channel volume $\left(V_{\mathrm{a}}\right)$ is defined as the total air-channel volume per weight of the samplc. Air channels refer to pores which connect with surfaces of the samples. As total pore volume per unit mass of the sample is identical with $V_{\mathrm{a}}+V_{\mathrm{b}}, V_{\mathrm{a}}$ is calculated as follows:

$$
V_{\mathrm{a}}=1 / \rho-1 / \rho_{\mathrm{i}}-V_{\mathrm{b}}
$$

where $\rho$ is the bulk density of the sample and $\rho_{\mathrm{i}}$ is the bubble-free icc density at $t^{\circ} \mathrm{C}$ (Bader, 1964).
Errors in the volume measurements were investigated using bubble-free singlc crystals of ice taken from Mendenhall Glacier, Alaska (Higashi, 1988). It was found that the standard deviation of the volume measurements of the ice samples was $0.11 \mathrm{~cm}^{3}$. Relations between sample volumes and analytical errors per unit mass $(\Delta V)$ are shown in Figure 2. Standard deviations per unit mass of ice are expressed by two curves. For $30-70 \mathrm{~g}$ ice samples, the errors in the measurements were in the range \pm 0.004 to $\pm 0.002 \mathrm{~cm}^{3} \mathrm{~g}^{-1}$, i.c. \pm 0.004 to $\pm 0.002 \mathrm{~m}^{3} \mathrm{Mg}^{-1}$.

Optical microscopic observation was conducted on thin-section samples from each ice core to investigate the air-bubble size, shape and configuration.



Fig. 2. The accuracy of bubble-volume measurements for bubble-free ice samples with slandard-deviation lines.

\section{RESULTS}

The positions, ice temperatures and annual accumulation rates of five ice-coring sites are summarized in Table 1. Results of bubble volumes $\left(V_{b}\right)$ and air-channel volumes $\left(V_{\mathrm{a}}\right)$ of these ice cores are shown in Figure 3. It should be noticed that air bubbles are rapidly formed at the following depth intervals: H23I (from about $41-49 \mathrm{~m}$ depth); Mizuho (about 44-53 m depth); G15 (about 63 $74 \mathrm{~m}$ depth); AC (about 72-80 $\mathrm{m}$ depth) and site J (about

Table 1. Glaciological dala and references for Antarctic and Greenland ice cores. $T_{\mathrm{c}}$ was measured at the following depths in the firn-ice transition layer: $H 231(40 \mathrm{~m})$, Mizuho Station $(51 \mathrm{~m}),(615(68 \mathrm{~m}), A C(80 \mathrm{~m})$ and sile $7(60 \mathrm{~m})$

\begin{tabular}{|c|c|c|c|c|}
\hline \multirow{2}{*}{ Site name } & Localion & Ice temperature & Accumulation rate & References for $T$ and $A$ data \\
\hline & long. & ${ }^{\circ} \mathrm{C}$ & m w.e. year $^{-1}$ & \\
\hline
\end{tabular}

\section{Antarctica}

\begin{tabular}{|c|c|c|c|c|c|}
\hline $\mathrm{H} 231$ & $69^{\circ} 46^{\prime} \mathrm{S}$ & $42^{\circ} 27^{\prime} \mathrm{E}$ & 25.4 & 0.11 & $\begin{array}{l}\text { Suzuki and Shiraishi (1982); Takahashi } \\
\text { and others (1994) }\end{array}$ \\
\hline Mizuho Station & $70^{\circ} 42^{\prime} \mathrm{S}$ & $44^{\circ} 22^{\prime} \mathrm{E}$ & -34.28 & 0.09 & Fujii (1978); Nakawo and others (1989) \\
\hline G15 & $71^{\circ} 11^{\prime} \mathrm{S}$ & $45^{\circ} 58^{\prime} \mathrm{E}$ & 37.8 & 0.10 & $\begin{array}{c}\text { Moore and others (1991); personal } \\
\text { communication from H. Narita }\end{array}$ \\
\hline $\mathrm{AC}$ & $74^{\circ} 12^{\prime} \mathrm{S}$ & $34^{\circ} 59^{\prime} \mathrm{E}$ & -43.8 & 0.06 & $\begin{array}{l}\text { Satake and others (1986); personal } \\
\text { communication from Y. Ageta }\end{array}$ \\
\hline \multicolumn{6}{|l|}{ Greenland } \\
\hline Site J & $66^{\circ} 52^{\prime} \mathrm{N}$ & $46^{\circ} 16^{\prime} \mathrm{W}$ & -16.7 & 0.39 & Shoji and others (1991) \\
\hline
\end{tabular}



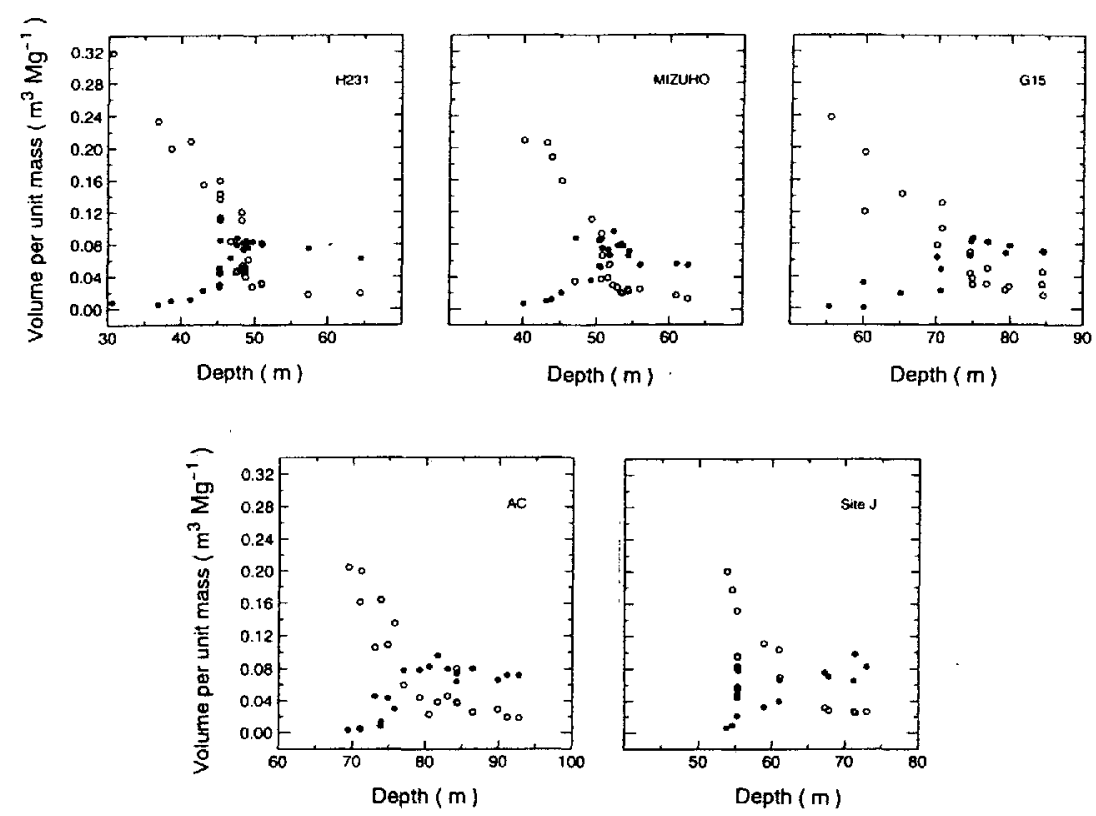

Fig. 3. Bubble volume and air-channel volumes versus depth in five ice cores from the Greenland and Antarctic ice sheets.

54-65 $\mathrm{m}$ depth). Air-channel volumes rapidly decrease in these depth intervals. 'These characteristic features of bubble formation are confirmed by microscopic observations on thin-section samples from each core.

\section{DISGUSSION}

An examination was made to find a relation between bulk density $(\rho)$ and bubble volume $\left(V_{b}\right)$ using the bubblevolume data in Figure 3. It was found that there is a linear relation between $\rho$ and $\ln \left(V_{\mathrm{b}}\right)$, as shown in Figure 4, in a density range from 0.75 to $0.825 \mathrm{Mg} \mathrm{m}^{-3}$. The straight line for the lower density of $0.825 \mathrm{Mg} \mathrm{m}^{-3}$ in Figure 4 is expressed as follows:

$$
\ln \left(V_{\mathrm{b}}\right)=48.466 \rho-42.38
$$

Bubble volume $\left(V_{\mathrm{b}}\right)$ and density $(\rho)$ are expressed in units of $\mathrm{m}^{3} \mathrm{Mg}^{-1}$ and $\mathrm{Mg} \mathrm{m}^{-3}$, respectively. The correlation

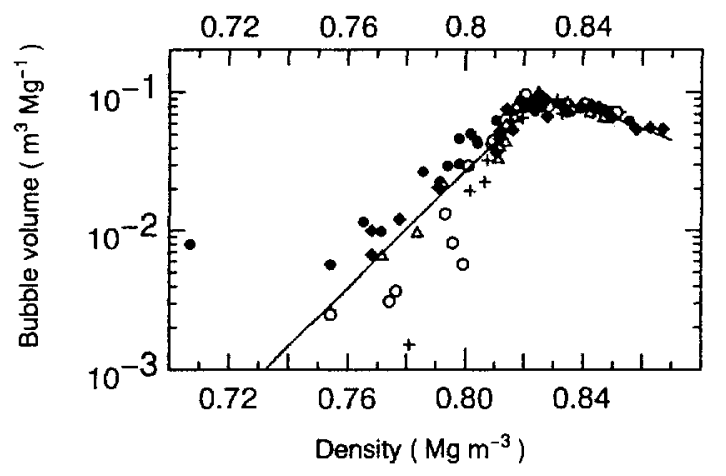

Fig. 4. Relation between logarithm of bubble volume $\left(\ln \left(V_{\mathrm{b}}\right)\right)$ and bulk density $(\rho)$ for five ice cores with calculated fit lines. coefficient and the degrees of freedom of this relation are 0.91 and 68 , respectively.

On the other hand, bubble volumes of ice samples at the higher density of $0.825 \mathrm{Mg} \mathrm{m}^{-3}$ decrease with bulk density as in the following equation, because the increase in ice density is caused by a decrease of total bubble volume:

$$
\begin{aligned}
V_{\mathrm{b}} & =\frac{\rho_{\mathrm{c}}}{\rho_{\mathrm{i}}-\rho_{\mathrm{c}}} \frac{\rho_{\mathrm{i}}-\rho}{\rho} V_{\mathrm{c}} \\
& =\left[\rho_{\mathrm{c}} \rho_{\mathrm{i}} V_{\mathrm{c}} /\left(\rho_{\mathrm{i}}-\rho_{\mathrm{c}}\right)\right]\left[1 / \rho-1 / \rho_{\mathrm{i}}\right]
\end{aligned}
$$

where $\rho_{\mathrm{c}}$ is a pore close-off density, at which firn turns into ice by the definition of ice, and $V_{c}$ is bubble volume per unit mass of ice at pore close-off.

We can determine the coefficient in Equation (4) using bubble-volume data, in which densities are over $0.825 \mathrm{Mg} \mathrm{m}^{-3}$ and also the average ice temperatures at five sites $\left(-31.19^{\circ} \mathrm{C}\right)$ are as follows:

$$
V_{\mathrm{b}}=0.7234\left[1 / \rho-1 / \rho_{\mathrm{i}}\right]
$$

where the correlation coefficient and the degrees of freedom are 0.62 and 33 , respectively

Bubble volumes in five ice cores with the calculated curves of Equations (3) and (5) are shown in Figure 5. They show a sharp increase from bulk density of about $0.78 \mathrm{Mg} \mathrm{m}^{-3}$ and have a peak value in bulk density between 0.820 and $0.830 \mathrm{Mg} \mathrm{m}^{-3}$. Bubble-volume profiles, expressed by the two curves, have the maximum value $\left(0.091 \mathrm{~m}^{3} \mathrm{Mg}^{-1}\right)$ at a bulk density of $0.825 \mathrm{Mg} \mathrm{m}^{-3}$.

Results of microscopic observation show that the number and mean diameter of the air bubbles depend on the mean annual temperatures at the coring site: the number of air bubbles per unit mass decreases with temperature and the mean diameter of air bubbles increases with temperature. However, these two factors contribute to an increase in the bubble volume in an opposite way and may cause the data scatter shown in Figure 5. 
Table 2. Values of $\rho_{\mathrm{cb}}$, porosity $s_{\mathrm{cb}}$, depth from surface $h_{\mathrm{cb}}$, overburden pressure $P_{\mathrm{cb}}$ and corresponding bubble volume $V_{\mathrm{cb}}$ for five ice cores

\begin{tabular}{lccccc}
\hline Site name & $\begin{array}{c}\rho_{\mathrm{cb}} \\
\mathrm{Mg} \mathrm{m}^{-3}\end{array}$ & $s_{\mathrm{cb}}$ & Depth & $P_{\mathrm{cb}}$ & $V_{\mathrm{cb}}$ \\
& & & $\mathrm{mPa}$ & $\mathrm{m}^{3} \mathrm{Mg}{ }^{1}$ \\
\hline H231 & 0.819 & 0.110 & 47 & 0.29 & 0.089 \\
Mizuho Station & 0.832 & 0.097 & 53 & 0.36 & 0.089 \\
G15 & 0.817 & 0.114 & 74 & 0.48 & 0.098 \\
AC & 0.821 & 0.110 & 80 & 0.52 & 0.094 \\
Site J & 0.825 & 0.102 & 65 & 0.42 & 0.092 \\
Average \pm S.D. & $0.823 \pm 0.005$ & $0.107 \pm 0.006$ & $64 \pm 12$ & $0.41 \pm 0.08$ & $0.092 \pm 0.003$ \\
\hline
\end{tabular}

In Figure 5, it seems that $V_{\mathrm{b}}$ of $\mathrm{H} 231$ and Mizuho are slightly higher than those of other cores in a density range $0.76-0.81 \mathrm{Mg} \mathrm{m}^{-3}$. In order to examine these regional differences of bubble volumes with bulk density, the above methods of two-curve fittings were again cmployed for each set of coring-site data.

$V_{b}$ with calculated two-fit curves for cach site are shown in Figure 6. The peak bubble volume probably corresponds to completion of the bubble-formation zone in the firn-ice transition layer. This bubble volume is denoted as $V_{\mathrm{cb}}$. Firn density at $V_{\mathrm{cb}}\left(\rho_{\mathrm{cb}}\right)$, porosity $\left(s_{\mathrm{cb}}=1-\rho_{\mathrm{cb}} / \rho_{\mathrm{i}}\right)$, overburden pressure $\left(P_{\mathrm{cb}}\right)$ and $V_{\mathrm{ch}}$, are summarized in Table 2 . It was found that $\rho_{\text {cb }}$ was in a density range $0.819-0.832 \mathrm{Mg} \mathrm{m}^{-3}$. The standard deviation of $\rho_{\mathrm{ch}}$ is $0.005 \mathrm{Mg} \mathrm{m}^{-3}$. This dcviation is almost the same as errors in density measurements $\left(=0.004 \mathrm{Mg} \mathrm{m}^{-3}\right)$

For cxamining rapid bubblc formation in the firn-ice transition zone, a $10 \%$ value of peak bubble volume is selected here as a reference parameter. 'This bubble volume seems to correspond to the initiation of the rapid bubble-formation zone in the firn-ice transition layer. This bubble volume is denoted as $V_{\text {ib }}$. Firn density at $V_{\mathrm{ib}}\left(\rho_{\mathrm{ib}}\right)$, porosity $\left(s_{\mathrm{ib}}\right)$, overburden pressure $\left(P_{\mathrm{ib}}\right)$ and $V_{\mathrm{ib}}$ are summarized in 'Table 3 . It was found that $\rho_{\mathrm{ib}}$, ranges from 0.763 to $0.797 \mathrm{Mg} \mathrm{m}^{-3}$. The standard deviation of $\rho_{\text {ib }}$ is $0.013 \mathrm{Mg} \mathrm{m}^{-3}$. The deviation is about three times larger than the error in the density measurements.

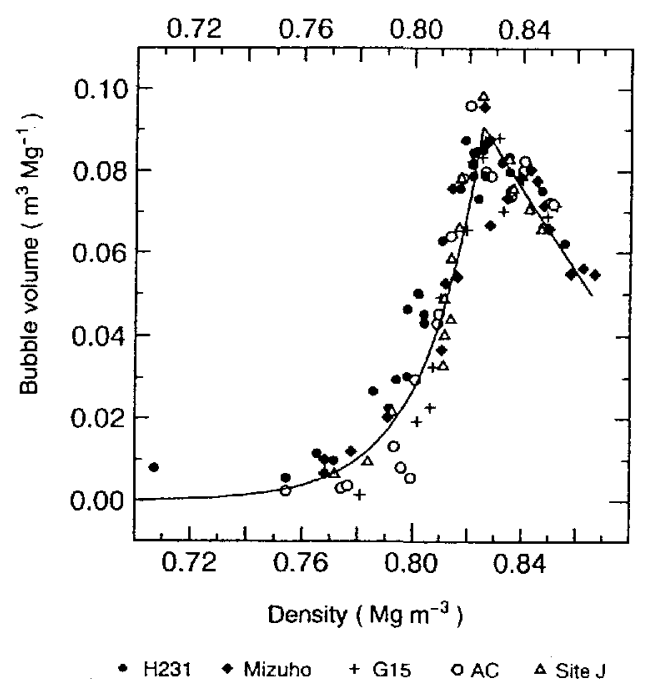

Fig. 5. Relation between air-bubble volume $\left(V_{\mathrm{b}}\right)$ and bulk density ( $\rho$ ) for five ice cores with calculated-fit curves.

The $\rho_{\mathrm{b} b}$ and $\rho_{\mathrm{cb}}$ with ice temperatures are shown in Figure 7. It seems that $\rho_{\mathrm{ib}}$ of four Antarctic ice cores has a correlation with ice temperature (correlation coefficient: $r=0.81)$. The value of $\rho_{\mathrm{ib}}$ at site $\mathrm{J}\left(0.780 \mathrm{Mgm}^{3}\right)$ was slightly larger than the expected value from four Antarctic ice cores. $\rho_{\mathrm{cb}}$ does not seem to be correlated with ice temperature or accumulation rate of the coring site.

Table 3. Values of $\rho_{\mathrm{ib}}$, porosity $s_{\mathrm{i}}$, depth from surface $h_{\mathrm{ib}}$, overburden pressure $P_{\mathrm{ib}}$ and $V_{\mathrm{ib}}\left(10 \%\right.$ of $\left.V_{\mathrm{cb}}\right)$ for five ice cores

\begin{tabular}{|c|c|c|c|c|c|}
\hline Site name & $\begin{array}{c}\rho_{\mathrm{ib}} \\
\mathrm{Mg} \mathrm{m}^{3}\end{array}$ & $s_{\mathrm{ib}}$ & $\begin{array}{c}\text { Deplh } \\
\mathrm{m}\end{array}$ & $\begin{array}{c}P_{\mathrm{ib}} \\
\mathrm{MPa}\end{array}$ & $\begin{array}{c}V_{\mathrm{ib}} \\
\mathrm{m}^{3} \mathrm{Mg}\end{array}$ \\
\hline $\mathrm{H} 231$ & 0.763 & 0.171 & 41 & 0.25 & 0.009 \\
\hline Mizuho Station & 0.768 & 0.165 & 44 & 0.28 & 0.009 \\
\hline G15 & 0.797 & 0.134 & 63 & 0.39 & 0.010 \\
\hline $\mathrm{AC}^{\mathrm{C}}$ & 0.791 & 0.140 & 72 & 0.46 & 0.009 \\
\hline Sitc J & 0.780 & 0.152 & 54 & 0.34 & 0.009 \\
\hline Average \pm S.D. & $0.780 \pm 0.013$ & $0.152 \pm 0.014$ & $55 \pm 12$ & $0.34 \pm 0.08$ & $0.009 \pm 0.000$ \\
\hline
\end{tabular}




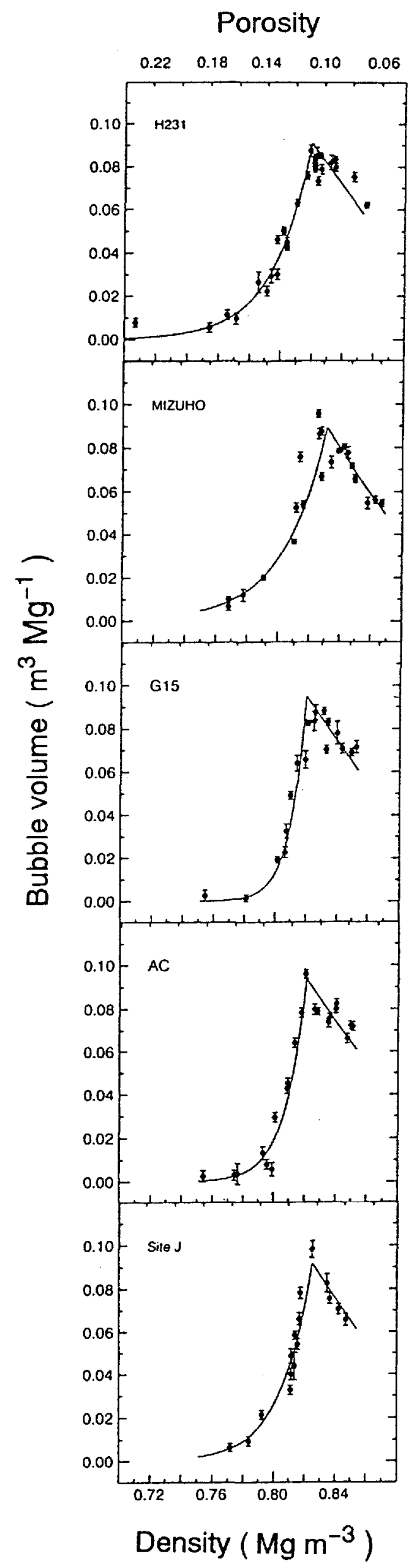

Fig. 6. Relation between bubble volume $\left(V_{\mathrm{b}}\right)$ and bulk density ( $\rho$ ) for each ice core with calculated fit curves.

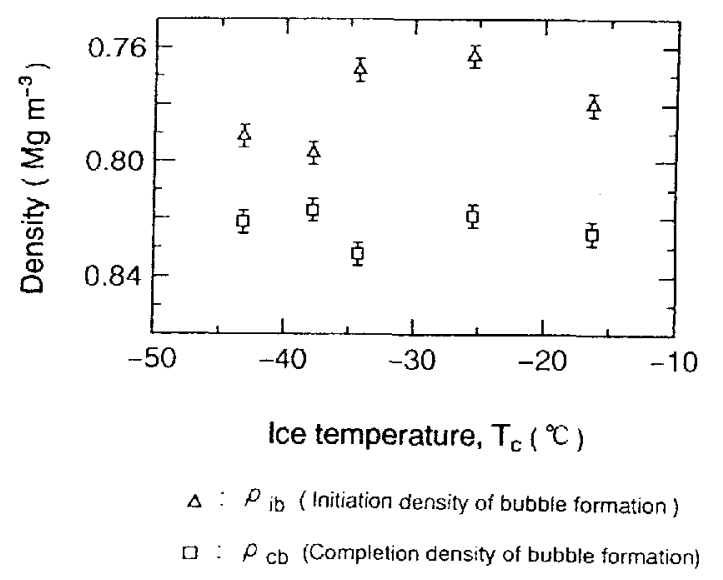

Fig. 7. Relation between ice temperature and $\rho_{\mathrm{il}}$, (triangles) and also ice temperature and $\rho_{\mathrm{cb}}$ (squares). $\rho_{\mathrm{Cl}, \mathrm{b}}$ is identical with peak bubble-volume density.

Overburden pressures for $\rho_{\mathrm{ib}}$ and $\rho_{\mathrm{cb}}$ (denoted as $P_{\mathrm{ib}}$ and $P_{\mathrm{cb}}$, respectivcly) in ice sheets and ice tempcratures are cxamined in Figure 8 . It was found that $P_{\mathrm{ib}}$ ranges from 0.25 to $0.46 \mathrm{MPa}$ and $P_{\mathrm{cb}}$ ranges from 0.29 to $0.52 \mathrm{MPa}$. A correlated relation between $P_{\mathrm{ib}}$ and icc temperature for four Antarctic ice cores is again observed $(r=0.93)$. A corrclated relation between $P_{\mathrm{cb}}$ and ice temperature $(r=0.92)$ is also observed.

Kameda and others (1994) have demonstrated that firn-density profiles in icc shcets are determined primarily by overburden pressure and firn tcmperature contributes to a lesser degree. Thus, density ranges from $\rho_{\mathrm{ib}}$ to $\rho_{\mathrm{ch}}$, in ice sheets are primarily detcrmined by these two parameters.

\section{CONGLUSION}

We have measured bubble volumes $\left(V_{b}\right)$ in the firn-ice transition layer using five ice cores from Greenland and Antarctica. It was found that $V_{b}\left(\mathrm{~m}^{3} \mathrm{Mg}^{-1}\right)$ in five icc

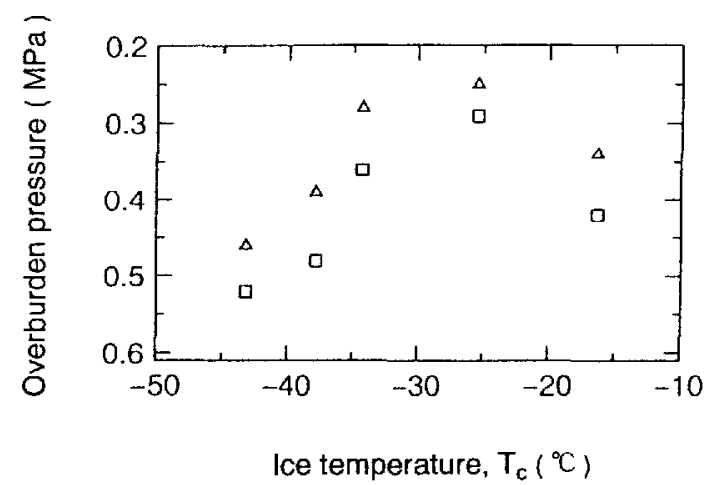

Irig. 8. Relation between ice temperature and $P_{\mathrm{ib}}$ (triangles) and also ice temperature and $P_{\mathrm{cb}}$ (squares). $P_{\mathrm{ib}}$ is identical with the overburden pressure, from which bubble volumes start to increase rapidly. $P_{\mathrm{c}}$, is identical with the overburden pressure at which bubble volume shows the maximum value by two-fit curves. 
cores was expressed by a function of density as in the following equations:

$$
\begin{aligned}
\ln V_{\mathrm{b}} & =48.466 \rho-42.38, & & 0.75<\rho<0.825\left(\mathrm{Mg} \mathrm{m}^{-3}\right) \\
V_{\mathrm{b}} & =0.7234\left(1 / \rho-1 / \rho_{\mathrm{i}}\right), & & 0.825<\rho .
\end{aligned}
$$

There is a regional difference for the profile of $V_{b}$ for each sitc; $V_{\mathrm{b}}$ in ice cores from warmer sites is slightly higher than those for ice cores from colder sites in a density range $0.76-0.81\left(\mathrm{Mg} \mathrm{m}^{-3}\right)$. Peak bubble volumes at which the above two lines are crossed $\left(V_{\mathrm{cb}}\right)$ are selected as a reference parameter. The $10 \%$ value of $V_{\mathrm{cb}}\left(V_{\mathrm{ib}}\right)$ is also selected as another reference parameter. It was found that $\rho_{\mathrm{ib}}$ (corresponding density of $V_{\mathrm{ib}}$ ) ranges from 0.763 to $0.791 \mathrm{Mg} \mathrm{m}^{-3}$ and $\rho_{\mathrm{cb}}$ (corresponding density of $V_{\mathrm{cb}}$ ) ranges from 0.819 to $0.832 \mathrm{Mg} \mathrm{m}^{-3}$. $\rho_{\mathrm{ib}}$ seems to be correlated with ice temperature in ice sheets $(r=0.81)$. The corresponding porosity of $\rho_{c b}$ does not seem to be correlated with ice temperature or accumulation rate. $P_{c b}$ (overburden pressure for $\rho_{c b}$ ) ranges from 0.29 to $0.52 \mathrm{MPa}$ and $P_{\mathrm{ib}}$ (overburden pressure for $\rho_{\mathrm{ib}}$ ) ranges from 0.25 to $0.46 \mathrm{MPa}$. A correlation between $P_{\mathrm{ib}}$ and ice temperature $(r=0.93)$ and also between $P_{\mathrm{cb}}$ and ice temperature $(r=0.92)$ is observed.

For further studies on the firn-ice transition, the icedeformation behavior should be considered as explaining the bubble formation and compression processes separately. In particular, the bubble-compression process in the firn-ice transition layer must be clarified quantitatively to understand the regional difference in the total air content in glacier ice and also for understanding the densification behavior of glacier ice after pore close-off.

\section{ACKNOWLEDGEMENTS}

Wc should like to thank Professor S. Mae and Dr M. Nakawo for useful suggestions prior to this study. We also acknowledge Professor E. Akitaya for support during the development of a measuring system for airbubble volume in ILTS, Hokkaido University. Fruitful discussions with Professors H. Shoji and S. Takahashi are acknowledged. Ice cores from Antarctica were recovered by the 21st, 24th, 25th and 26th Japanese Antarctic Research Expeditions in the Glaciological Research Program in east Dronning Maud Land. The recovery of the site $\mathrm{J}$ icc core was supported by a grant-in-aid from the International Scientific Research Program of the Japanese Ministry of Education, Science and Culture.

\section{REFERENCES}

Bader, H. 1964. Density of ice as a function of temperature and stress. CRREL Spec. Rep. 64.

Fujii, Y. 1978. Miscellaneous compiled data. V1. Temperature profile in the drilled hole, Mem. Natt Inst. Polar Res. Spec. Issue, 10, 169.

Higashi, A., ed. 1988. Lattice defects in ice crystals. Sapporo, Japan, Hokkaido University Press.

Kameda, T., H. Shoji, K. Kawada, O. Watanabe and H. B. Clausen. 1994. An empirical relation between overburden pressure and firn density. Ann. Glaciol, 20 (see paper in this volume).

Langway, C.C., Jr, H. Shoji, A. Mitani and H. B. Clausen. 1993. Transformation process observations of polar firn to ice. Ann. Glaciol., 18, 199-202.

Macno, N., H. Narita and K. Araoka. 1978. Mcasurements of air permeability and elastic modulus of snow and firn drilled at Mizuho Station, East Antarctica. Mem. Nall Inst. Polar Res. Spec. Issue., 10, 62-76.

Martinerie, P., D. Raynaud, D. M. Etheridge, J.-M. Barnola and D. Mazaudier, 1992. Physical and climatic parameters which influence the air content in polar ice. Earth Planet. Sci. Lett., 112, 1-13.

Moore, J. C., H. Narita and N. Maeno. 1991. A continuous 770-year rccord of volcanic activity from East Antarctica. 7. Geophys, Res, 96(D9), 17,353-17,359.

Nakawo, M., H. Ohmae, F. Nishio and T. Kameda. 1989. Dating the Mizuho $700-\mathrm{m}$ core from core ice fabric data. Proceedings of the National Institute of Polar Research (Tokyo) Symposium on Polar Meteorology and Glaciology, 2, 105-110.

Satake, H., K. Kawada, K. Tsushima and N. Sato. 1986. Isotope study of depositional environment in cast Queen Maud Land, Antarctica. Tritium Research Center Report (Toyama University)., 6, 57-69 (In Japanese with English abstract.)

Schwander, J. and B. Stauffer. 1984. Age difference between polar ice and the air trapped in its bubbles. Nalure, 311(5981), 45-47.

Schwander, J. and 6 others. 1993. The age of the air in the firn and the ice at Summit, Grecnland. 7. Geophys. Res., 98(D)2), 2831-2838.

Shoji, H., H. B. Clausen and T. Kameda. 1991. Accumulation rate at Site $J$ and Dye 2, Greenland. Bull. Glacier Res., 9, 85-88.

Stauffer, B., J. Schwander and H. Oeschger. 1985. Enclosure of air during metamorphosis of dry firn to ice. Ann. Glaciol., 6, 108-112.

Suzuki, Y. and K. Shiraishi. 1982. The drill system used by the 21 st Japanese Antarctic Rescarch Expedition and its later improvement. Mem. Natl Inst. Polar Res. Spec. Issue, 24, 259-273.

Takahashi, S., Y. Ageta, Y. Fujii and O. Watanabe. 1994. Surface mass balance on east Dronning Maud Land in Antarctica observed by Japanese Antarrtic Research Expeditions. Ann. Glaciol, 20 (see paper in this volume).

The accuracy of the references in the text and in this list is the responsibility of the authors, to whom queries should be addressed. 